\title{
OPTIMASI PENURUNAN DEFECT PADA PRODUK MEBLE BERBASIS POLYPROFILEN MENGGUNAKAN METODE SIX SIGMA, FMEA, DAN ANOVA UNTUK MENINGKATKAN KUALITAS
}

\author{
Muhammad Yusuf \\ Dosen Teknik Industri Universitas Pamulang \\ yusufyusay@rocketmail.com
}

\begin{abstract}
ABSTRAK
Penelitian ini untuk menganalisa optimasi meningkatkan kualitas produk meble berbasis PP, tujuan penelitian ini untuk menurunkan defect produk meble berbasis PP, pengendalian produk meble hasil menunjukkan produk defect yang dominan pada proses produksi meble adalah defect tertarik, penerapan perbaikan dengan menggunakan metode Six Sigma, FMEA, Anova untuk dapat menurunkan defect tertarik, hasil penelitian menunjukkan nilai DPU sebesar 0,50\%, hasil analisis anova menunjukkan perbedaan yang signifikan dan mempunyai nilai mean sebesar 0,50.
\end{abstract}

Kata Kunci: Pengendalian Kualitas, Six Sigma, Anova.

\section{PENDAHULUAN}

Produk cacat merupakan barang atau jasa yang dibuat dalam proses produksi namun memiliki kekurangan yang menyebabkan nilai mutunya kurang baik atau kurang sempurna.

Cacat produk adalah produk yang tidak sesuai standar mutu. Pengaruh produk cacat pada perusahaan berdampak pada cost quality, nama baik perusahaan dan kepuasan konsumen (Hansen \& Mowen). Jika dalam proses produksi banyak produk cacat maka akan semakin banyak biaya yang dikeluarkan pada proses produksi. Produk cacat dapat dicegah dengan cara proses produksi dengan benar pada awal. Pencegahan dapat dilakukan dengan cara meningkatkan pengecekan baku sebelum diproses. Banyak nya produk yang cacat dapat menghambat kencaran proses produksi. Perwatan mesin yang tadak berjalan mengakibatkan karyawan melakukan proses secara manual. Sehingga dapat menigkatnya defect (cacat) yang mengakibatkab penurunan kualitas.

PT. Polymindo Permata yang berlokasi di Tangerang adalah perusahaan manufakture yang bergerak dibidang ekstrusi plastik untuk bahan furniture, handicraft, building partition, surface wall and ceiling dan subroof part. PT.Polymindo Permata telah menghasilkan banyak produk dalam setiap tahunnya. Adalah produk V3RO70 -
Twisted Hyacinth A3 Natural sebagai salah satu produk plastic furniture unggulan di PT.Polymindo Permata dan menjadi produk yang paling diminati oleh customer (stock non customized). Produk Twisted adalah produk turunan dari fiber Strapping Polystrap Natural Hyacinth Roll yang dilakukan proses Twisting menggunakan mesin yang memiliki desain dan kinerja khusus. Dimana produk lembaran fiber akan diproses menjadi sedemikian rupa sehingga mempunyai nilai jual yang lebih tinggi dari produk sebelumnya. Tetapi pada setiap proses produksinya, tidak terlepas dari kemungkinan akan terjadinya produk cacat atau defect. PT. Polymindo Permata telah melakukan kontrol untuk mengurangi produk V3R070 - Twisted Hyacinth A3 Natural yang mengalami defect (cacat), tetapi semua jenis kerusakan tersebut pasti akan terjadi. Berikut adalah data produksi produk V3R070 - Twisted Hyacinth A3 Natural yang OK dan produk cacat di PT.Polymindo Permata antara tahun 2017 hingga 2018 : 
Tabel 1.1 Kuantitas produk Good dan Reject periode Oktober 2017 - Oktober 2018

\begin{tabular}{|c|c|c|c|c|c|c|c|c|c|}
\hline \multirow{2}{*}{ No } & \multirow{2}{*}{$B \ln$} & \multirow{2}{*}{$\begin{array}{c}\text { Qty.Good } \\
(\mathrm{Kg})\end{array}$} & \multirow{2}{*}{$\begin{array}{l}\text { Qty.Reje } \\
\text { ct }\end{array}$} & \multicolumn{6}{|c|}{ Qty. Produk Cacat/Reject (Kg) } \\
\hline & & & & $\begin{array}{l}\text { Tertari } \\
\mathrm{k}\end{array}$ & $\begin{array}{l}\text { Visual } \\
\text { Kendor } \\
\end{array}$ & $\begin{array}{l}\text { Tergese } \\
\mathrm{k}\end{array}$ & $\begin{array}{l}\text { Berat } \\
\text { Lebih }\end{array}$ & Bercak & $\begin{array}{c}\text { Dimensi } \\
\text { Labil } \\
\end{array}$ \\
\hline 1 & Okt-17 & 412.57 & 142.04 & 59.89 & 26.64 & 16.82 & 20.22 & 18.47 & 0 \\
\hline 2 & Nov-17 & 429.82 & 67 & 47.19 & 16.72 & 0 & 3.09 & 0 & 0 \\
\hline 3 & Des-17 & 360.89 & 91.85 & 34.14 & 26.79 & 0 & 11.25 & 19.67 & 0 \\
\hline 4 & Jan-17 & 1013.72 & 129.72 & 56.12 & 18.37 & 32.84 & 0 & 11.52 & 10.87 \\
\hline 5 & Feb-17 & 1870.74 & 134.17 & 46.02 & 33.69 & 35.54 & 3.9 & 7.02 & 8 \\
\hline 6 & Mart-17 & 1046.05 & 93.57 & 55.97 & 18.22 & 0 & 14.26 & 0 & 5.12 \\
\hline 7 & Apr-17 & 64.26 & 26.36 & 0 & 15.36 & 0 & 0 & 0 & 11 \\
\hline 8 & Mei-17 & 94.03 & 74.54 & 57.07 & 0 & 0 & 0 & 17.47 & 0 \\
\hline
\end{tabular}

\begin{tabular}{|c|c|c|c|c|c|c|c|c|c|}
\hline \multirow{2}{*}{ No } & \multirow{2}{*}{ Bln } & \multirow{2}{*}{$\begin{array}{c}\text { Qty.Good } \\
\text { (Kg) }\end{array}$} & \multirow{2}{*}{$\begin{array}{c}\text { Qty.Reje } \\
\text { ct } \\
(\mathrm{Kg})\end{array}$} & \multicolumn{6}{|c|}{ Qty.Produk Cacat/Reject (Kg) } \\
\hline & & & & $\begin{array}{l}\text { Tertari } \\
\mathrm{k}\end{array}$ & $\begin{array}{l}\text { Visual } \\
\text { Kendor } \\
\end{array}$ & $\begin{array}{l}\text { Tergese } \\
\mathrm{k}\end{array}$ & $\begin{array}{l}\text { Berat } \\
\text { Lebih } \\
\end{array}$ & Bercak & $\begin{array}{c}\text { Dimensi } \\
\text { Labil } \\
\end{array}$ \\
\hline 9 & Jun-18 & 983.25 & 173.82 & 35.64 & 34.84 & 33.14 & 52.48 & 17.72 & 0 \\
\hline 10 & Jul-18 & 223.46 & 80.93 & 46.37 & 29.29 & 0 & 5.27 & 0 & 0 \\
\hline 11 & Agust-18 & 164.75 & 116.86 & 34.29 & 0 & 36.04 & 31.06 & 0 & 15.47 \\
\hline 12 & Sep-18 & 505.57 & 69.81 & 42.84 & 0 & 0 & 11.25 & 15.72 & 0 \\
\hline 13 & Okt-18 & 517.23 & 100.48 & 32.04 & 16.82 & 34.84 & 16.78 & 0 & 0 \\
\hline \multicolumn{3}{|c|}{ Persentase $(\%)$} & $16.9 \%$ & $7.1 \%$ & $3.1 \%$ & $2.5 \%$ & $2.2 \%$ & $1.4 \%$ & $0.7 \%$ \\
\hline
\end{tabular}

Sumber : Data internal PT.Polymindo Permata yang diolah

Berdasarkan data tabel 1.1 di atas, produk cacat pada setiap bulannya mengalami fluktuasi. Total tingkat kecacatan produk yang terjadi pada produk V3R070 - Twisted Hyacinth A3 Natural mencapai angka 16.90\% dari total hasil produksi yang dihasilkan selama satu tahun. Padahal PT. Polymindo Permata telah berusaha melakukan perbaikan dengan menetapkan standar defect 5\%. Tetapi masih dinilai belum optimal sehingga dilakukan analisa dalam upaya cacat produk dalam terjadi penurunan dengan mencari sebab masalah yang ada dan mendapatkan solusi yang baik dengan dengan metode atau alat bantu, tujuan defect produk dapat ditekan sekecil mungkin sehingga target produksi tercapai. Serta perlu dilakukan penelitian apakah dengan penggunaan metode Six Sigma dapat meminimalisir produk cacat (defect) guna mencapai tingkat standarisasi dan target yang ditetapkan perusahaan. 


\section{DASAR TEORI}

\subsection{Cacat Produk/Defect}

Produk cacat adalah produk yang tidak sesuai dengan standar mutu yang telah ditetapkan secara ekonomis dan tidak dapat diperbaharui menjadi produk yang layak jual (Mulyadi).

"Produk harus sesuai dengan spesifikasinya dalam memenuhi kebutuhannya, untuk berfungsi sebagaimana mestinya produk dibuat. Produk itu dinyatakan rusak apabila produk tersebut tidak memenuhi spesifikasinya (Hansen \& Mowen)."

"Produk rusak adalah produk yang dihasilkan dalam proses produksi, dimana produk yang dihasilkan tersebut tidak sesuai dengan standar mutu yang ditetapkan, tetapi secara ekonomis produk tersebut dapat diperbaiki dengan mengeluarkan biaya tertentu, tetapi biaya yang dikeluarkan cenderung lebih besar dari nilai jual setelah produk tersebut diperbaiki. Produk rusak ini pada umumnya diketahui setelah proses produk selesai (bastian \& Nurlela)."

\subsection{Pengendalian Kualitas Produk}

\subsubsection{Pengertian Pengendalian}

Pengendalian adalah suatu kegiatan pengendalian dilaksanakan dengan cara memonitor keluaran (output), membandingkan dengan standar - standar, menafsirkan perbedaan - perbedaan dan mengambil tindakan untuk menyesuaikan kembali proses-proses itu sehingga sama/sesuai dengan standar. Pengendalian merupakan kegiatan yang dilakukan untuk menjamin agar kegiatan proses produksi dan operasi dapat berjalan sesuai dengan apa yang diharapkan oleh pihak perusahaan dan apabila terjadi penyimpangan

\section{METODOLOGI}

\section{Six Sigma}

Six Sigma dapat didefiniskan sebagai metode peningkatan proses bisnis yang bertujuan untuk menemukan dan mengurangi penyebab kegagalan pada proses produksi atau waktu siklus proses serta biaya proses, guna memenuhi kebutuhan pelanggan dengan cara meningkatkan produktivitas, mencapai target dan nilai dapat dikoreksi sehingga apa yang diharapkan tercapai (Buffa)

\subsubsection{Pengertian Kualitas}

Kualitas didefinisikan sebagai kesesuaian dengan persyaratan, bukan "kebaikan." Sistem untuk mencapai kualitas adalah pencegahan, bukan penilaian.

Standar kinerja adalah nol cacat, bukan yang cukup dekat. Pengukuran kualitas adalah harga ketidaksesuaian, bukan indeks. Namun pada dasar nya konsep kualitas yaitu kesesuaian ciri-ciri atau karekteriktik produk yang sesuai harapan pelanggan itu sendiri.

Menurut Deming (1986) kualitas adalah mentranslate untuk mengubah kebutuhan yang akan datang dari penggunan kedalam suatu karakteristik yang diperlukan agar sebuah produk dapat di desain dan dibuat untuk memberikan kepuasan dengan harga yang dibayar oleh pengguna.

a. Kualitas merupakan suatu kondisi dinamis yang berhubungan dengan produk, jasa, manusia, proses dan lingkungan yang memenuhi atau melebihi harapan (Goestch \& David).

b. Kualitas adalah kelayakan atau kecocokan dalam penggunaan (Jurran).

c. Kualitas adalah kesesuaian dari permintaan dari spesifikasi ( conformance to requirement ). Sehingga dapat disimpulkan bahwa kualitas merupakan kesesuaian atau kecocokan suatu produk yang dihasilkan oleh perusahaan yang dengan spesifikasi yang diharapkan oleh pelanggan (Grosby, 1979).

tambah produksi maupun pelayanan. (Evans dan Lindsay, 2007, P3)

2. Analisis Anova

Analisis Of Variance atau Anova merupakan salah satu teknik analisis multivariate yang berfungsi untuk membedakan rerata lebih dari dua kelompok data dengan cara membandingkan variansinya, analisis varian termasuk dalam kategori statistik 
parametric, sebagai alat parametric maka untuk dapat menggunakan rumus Anova harus terlebih dahulu perlu dilakukan uji asumsi meliputi normalitas, heterokedastisitas dan random sampling (Ghazali, 2009)

\section{HASIL DAN PEMBAHASAN}

1. Uji Six Sigma

Tabel 4.24 Resume of Defective (After)

\begin{tabular}{|l|c|}
\hline Item from graph & Value \\
\hline Mean Defective (\%) & 0.00501 \\
\hline Confidence Interval (\%) & $95 \%$ \\
\hline$\ldots \ldots . . . .$. & 0.02279 \\
\hline LCL & 0 \\
\hline Target Defective (\%) & 0 \\
\hline Opportunity of Defect (CTQ) & 5 \\
\hline
\end{tabular}

2. Menghitung DPMO

a. Menghitung Defect Per Unit (DPU)

Dari perhitungan diketahu DPU yaitu 0.00501

b. Menghitung jumlah Opportunity (Opp)

Jumlah opportunity untuk tiap produk yaitu 5 (potential CTQ).

c. Menghitung Defect Per Opportunity (DPO) 0.001002 d. Menghitung jumlah Defect Per Million Opportunity (DPMO)

$\mathrm{DPMO}=\mathrm{DPO} \times 1.000 .000=$ $0.001002 \times 1.000 .000=1002$

Berdasarkan analisa control chart pada gambar 4.18 dan 4.19 , untuk defect tertarik pada produk dalam keadaan terkendali secara statistik. Artinya setelah melalui tahapan DMAIC ini maka dapat diperoleh hasil kondisi sebagai berikut :

Tabel 4.18 Kondisi Setelah Tahapan DMAIC

\begin{tabular}{|l|c|c|}
\hline Kondisi & Sebelum & Setelah \\
\hline DPU & $12.77 \%$ & $0.50 \%$ \\
\hline Improvement & Tidak di cek QC & Di cek QC (sortir) \\
\hline Proses Strapping & Tidak selaras & $\begin{array}{c}\text { Selaras (dipasang alat } \\
\text { Synchronized) }\end{array}$ \\
\hline $\begin{array}{l}\text { Putaran Bobbin dan } \\
\text { HOB }\end{array}$ & &
\end{tabular}




\begin{tabular}{|l|l|c|} 
& & $\begin{array}{c}\text { Pen yang sudah aus tidak } \\
\text { digunakan lagi saat proses } \\
\text { produksi. }\end{array}$ \\
\hline
\end{tabular}

\section{Uji Anova}

Uji one way anova perbaikan_0, perbaikan_1, perbaikan_2, perbaikan_3, perbaikan_4, perbaikan_5, perbaikan_6, dan perbaikan_7

Berdasarkan tabel hasil perhitungan di atas untuk nilai $\mathrm{p}$-value $<0.05$ (hasil $=0.000$ ) dan

1. Produksi produk fiber di PT.Polymindo Permata seperti produk V3R070 - Rope Hyacinth A3 Natural tidak terlepas dari berbagai jenis defect dan masalah produksi. defect yang paling sering terjadi adalah defect karena visual tertarik sehingga menyebabkan perubahan deformasi pada bentuk produk.

2. Faktor - faktor penyebab defect yaitu:

a. Bahan part (For-twist) tidak dilakukan pengecekan oleh QC, hal ini mengakibatkan banyaknya produk defect (visual keropos dan berpori),

b. Tidak adanya alat penyelaras putaran (Synchronized) sehingga putaran bobin dan Hob tidak sama, sehingga mengakibatkan banyaknya produk defect (visual tertarik dan melipat)

c. Pen pada bobin sudah aus sehingga mengakibatkan banyaknya produk defect (visual kendur)

3. Dari hasil pengujian dengan menggunakan metode Anova terdapat perbedaan signifikan antara percobaan sebelum dengan setelah perbaikan.

4. Langkah - langkah perbaikan untuk menurunkan tingkat defect visual tertarik dalam penelitian ini santara lain : derajat kebebasan $=56$, menunjukkan perbedaan yang signifikan antara

\section{KESIMPULAN}

a. Melakukan proses inspeksi QC (sortir) terhadap proses Strapping. Seperti diketahui proses Strapping sebelumnya tidak dilakukan QC namun langsung ke proses Twisting.

b. Menyelaraskan putaran mesin Bobbin dan speed $\mathrm{HOB}$ pada mesin Twisting menggunakan alat Synchronized. Penyelarasan putaran tersebut dimaksudkan agar tidak terjadi over speed atau late speed pada kedua mesin rotary system sehingga produk fiber tidak menjadi tertarik.

c. Melakukan penggantian pen yang sudah haus agar tidak digunakan lagi untuk proses produksi.

\section{DAFTAR PUSTAKA}

Buffa, E. S. (1999). Modern Production/Operations Management (8 ed.). New York: John Wiley \& Sons.

Deming, W. E. M. (1986). Out of Crisis, Massachusetts Institute of. Technology. Center for Advanced Engineering Study. Boston: Massachusetts.

Garvin \& Davis. (2005). Manajemen Mutu Terpadu. In M.N. Nasution (Ed.). Jakarta: Erlangga.

Gasperz, V. (2002). Pedoman Implementasi Six Sigma Teintegrasi dengan ISO 9001:2000, MBNQA, dan HACPP. Jakarta: Gramedia Pustaka Utama. 
$p-I S S N: 2620-5793$

$e-I S S N$ : $2685-6123$

Gasperz, V. (2005). Total Quality Management. Jakarta: Gramedia Pustaka Utama.

Goetsch dan Davis. (1994). Manajemen Mutu Terpadu: Total Quality Management (2 ed.). Bogor: Ghalia Indonesia.

Hansen \& Mowen. (2001). Manajemen Biaya. In Benyamin Molan (Ed.) (2 ed., hal. 633). Jakarta: Penerbit Salemba Empat.

Heizer, J., \& Render, B. (2006). Principles of Operations Management. Genes genetic systems. 